\title{
La espectrometría de emisión con fuente de plasma de acoplamiento inductivo
}

\section{Inductively coupled plasma emission spectrometry}

\section{RESUMEN}

La técnica de espectroscopia de emisión con fuente de Plasma de acoplamiento Inductivo (ICP), surgida como un avance en la espectroscopia tradicional de emisión, ha hecho posible la cuantificación, inclusive como traza de los elementos de una muestra gracias a la eliminación de la mayor parte de las interferencias quimicas.

En el presente trabajo se ofrece una visión del tema al introducir al lector en esta técnica, mediante la consideración de las partes fundamentaies del equipo ICP. del modo de proceder a la hora de llevar a cabo un análisis, tanto cualitativo como cuantitativo, y de las posibles aplicaciones de ésta, en especial en el campo de los conglomerantes hidraúlicos, cuyo desarrollo dará lugar a futuras investigaciones.

\author{
M. ISABEL SANCHEZ DE ROJAS, Dra. en C. Químicas \\ M. PILAR DE LUXAN, Dra. en C. Químicas \\ IETcc/CSIC
}

MOISES FRIAS, Lcdo. en C. Químicas

\section{INTRODUCCION}

En estos últimos años los investigadores se han visto inmersos en un sin fin de técnicas instrumentales, nuevas unas, conocidas, pero modificadas, otras. Todas ellas mejoran y simplifican los métodos de análisis tradicionales.

Los avances tecnológicos en la espectroscopia de emisión óptica han hecho posible la utilización de esta técnica para la cuantificación de los elementos en una sola muestra, al introducir las fuentes de excitación por "PLASMA".

Los trabajos pioneros sobre la formación y estabilización de estos plasmas, se deben a T.B. Reed en los años sesenta, (1), (2), y fueron la base de los primeros estudios analíticos para determinaciones de trazas de elementos metálicos, mediante el uso de plasmas acoplados inductivamente como

\section{$S U M M A R Y$}

Inductively coupled plasma emission spectroscopy technique (ICP) raised as a step forward in traditional emission spectroscopy, has allowed the quantification, even from a trace, of the elements of a sample by means of the elimination of most of the chemical interferences.

In this paper, a view of the subjet is given, introducing the reader to this technique through the consideration of the essential parts of the ICP system, of the way to proceed when a qualitative and quantitative analysis is to be carried out, and its possible applications, specially in hydraulic binders, which development will bring the opportunity for future researches.

\section{INTRODUCTION}

For the past few years, researchers have been immersed in countless instrumental techniques, some of which are new, while other well-known ones have been modified. All these techniques improve and simplify traditional methods of analysis.

Technological progress in optical emission spectroscopy has made it possible to use this technique to quantify elements in a single sample by introducing "PLASMA" excitation sources.

T. B. Reed was responsible for pioner studies in the 1960's, (1) (2), on the formation and stabilization of this plasma which formed the basis of initial analytic studies for determining traces of metallic elements, by means of using inductively coupled plasma as excitation sources, which amerged simultaneously in Great Britain thanks to S. Greenfield and col., 
fuentes de excitación y que surgieron de forma simultánea en Inglaterra, por S. Greenfield y col., (3) (4), y en USA, por V. A. Fassel y col., (5) (6), aunque se llevaron a cabo de forma independiente.

A partir de los años 70 , comienza la difusión de esta técnica en los laboratorios de investigación, los primeros equipos comerciales datan de 1974, y aparecen los primeros estudios de aplicación de diversos ámbitos (7), (8), (9), (10), (11), (12).

Actualmente, se va ampliando el campo de aplicación, al emplearse en el análisis cuantitativo en una gran gama de especialidades (13), (14), (15), (16), (17), lo que le hace merecer una consideración especial en investigación analítica.

El objetivo de este trabajo es la descripción de un equipo de Emisión por Plasma Acoplado Inductivamente, de reciente adquisición por el Centro, así como las primeras aplicaciones analíticas en la investigación de los conglomerantes hidráulicos, que dejan abierta una nueva vía en el estudio de materias primas (caliza, arcilla...), cementos con base portland (clinker, yeso, diferentes adiciones, ...), áridos, ...

Desde que, en 1980, K. Takemoto y col. (18) indicaron la validez de la espectroscopía de emisión ICP para el análisis de trazas en cementos y productos análogos, mencionando a J. O. Burman y col. (19) en la aplicación de cuarcitas y a R. H. Scott y col. (20) en estudio de suelos, los artículos aparecidos en la bibliografía acerca de este campo, son recientes y todavía escasos; cabe citar, entre otros, a J. Debras-Guedon en el análisis de materias primas y productos de las industrias cerámicas, cementeras y del vidrio (21) (22), a J. P. Degre en el control de escorias y cenizas volantes (23) y cementos (24), a R. A. Nadkarni y col. en el análisis elemental de materiales geológicos (25), y a A. M. Marabini y col. en la determinación de uranio en rocas (26).

Mediante esta técnica es posible la determinación cualitativa y cuantitativa de los elementos químicos que constituyen un material con gran rapidez, precisión y exactitud. Se exponen casos prácticos en cada una de estas vertientes.

\section{ESPECTROMETRIA DE EMISION POR FUENTE DE PLASMA ACOPLADO INDUCTIVAMENTE}

\subsection{Fundamentos de la técnica}

Al ser una técnica relativamente moderna, los
(3) (4), and in the U.S.A., conducted by V. A. Fassel and col. (5) (6), even though these investigations were carried out quite separately.

From the 1970's onwards, this technique starts to propagate in research laboratories, with the first set of commercial equipment dating back to 1974, and the appearance of the first studies of application for different fields (7), (8), (9), (10), (11), (12).

Nowadays, the field of application is being amplied by using it in quantitative analysis in a wide range of specialities (13), (14), (15), (16), (17), making it worthy of special consideration in analytic research.

The object of this paper is to describe a Inductively Coupled Plasma Emission system, recently acquired by the Centre, as well as the first analytic applications in research on hydraulic binders, which open up a new path in the study of raw materials (limestone, clay, ...), portland-based cements (clinker, gypsum, different additions, ...), aggregates, ...

Since K. Takemoto and col. (18) pointed out the validity of ICP emission spectrometry for analyzing traces in cements and similar products in 1980, mentioning J. O. Burman and col. (19) in the application of quartzites and R. H. Scott and col. (20) in the study of soils; the papers that have appeared in the bibliography concerning this field have all been written recently and are still very few in number; among others should be mentioned $J$. Debras-Guedon in the analysis of raw materials and products for ceramic industries, cement works and glass works (21), (22), J. P. Degre in the control of slag and fly ash (23) and cements (24), R. A. Nadkarni and $\mathrm{col}$. in the basic analysis of geological materials (25), and A. M. Marabini and col. in the determination of uranium in rocks (26).

By means of this technique it is possible to determine both qualitatively and quantitatively the chemical elements that go to make up a material with high-velocity, precision and accuracy. Practical cases are provided for each of these aspects.

\section{INDUCTIVELY COUPLED PLASMA-ATOMIC EMISSION SPECTROSCOPY}

\subsection{Basic principles of the technique}

Owing to the fact that this is a relatively 
primeros trabajos publicados son eminentemente teóricos, y exponen de manera detallada los fundamentos de la misma (7), (11), (12), (27), (28), (29), por ello sólo se mencionan a continuación muy brevemente.

PLASMA es un gas ionizado, eléctricamente neutro, confinado en un tubo de descarga. En su aplicación espectroscópica se denomina plasma a un gas parcialmente ionizado (basta con que lo estén el $1 \%$ de sus átomos o moléculas), eléctricamente neutro en su conjunto y confinado en un campo electromagnético, existiendo un equilibrio entre partículas cargadas y neutras.

Existen diferentes tipos de plasma en función de la forma de conseguir dicho equilibrio.

Los campos magnéticos pueden interaccionar con los plasmas. Una de estas interacciones es un acoplamiento inductivo de campos magnéticos variantes en el tiempo con el plasma.

En el plasma ICP (Inductively Coupled Plasma), la ionización se realiza mediante una corriente inducida de alta frecuencia.

Las temperaturas en un plasma ICP son muy elevadas $\left(4.000-10.000^{\circ} \mathrm{K}\right)$ y son suficientes para disociar las combinaciones químicas estables, incluso los óxidos refractarios, eliminándose las interferencias químicas. Estos plasmas pueden estar o no en equilibrio termodinámico.

Para conseguir la ionización se hace circular el gas por una serie de tubos concéntricos, que constituyen la "ANTORCHA", pieza clave en un equipo de plasma. Al final de la misma se encuentra una bobina de inducción, alimentada por un generador de alta frecuencia.

En principio, es necesario iniciar la ionización del gas utilizando un medio auxiliar, chispa Tesla que luego se mantiene por la corriente de alta frecuencia que fluye a través de la bobina de inducción. El efecto es la aparición de un campo magnético, cuyas líneas de fuerza se orientan axialmente a la bobina, e induce a los iones y electrones a moverse en órbitas circulares, creando corrientes eléctricas, que a causa del efecto Joule ocasionan un calentamiento de los gases, alcanzándose temperaturas de hasta $10.000^{\circ} \mathrm{K}, \mathrm{y}$ proporcionan la continuidad del plasma.

En el extremo de la antorcha aparece, debido a los átomos ionizados, una especie de modern technique, the first published studies on the subject are eminently theoretical, providing detailed explanations of its basic principles (7), (11), (12), (27), (28), (29); for this reason they are only mentioned briefly below.

PLASMA is an ionized gas, which is electrically neutral and confined in a brush discharge. In its spectroscopic application, plasma refers to a partially ionized gas (having $1 \%$ of its atoms or molecules ionized is enough), which is electrically neutral as a whole and confined in an electromagnetic field, with an equilibrium existing between charged and neutral particles.

There are various types of plasma according to the method employed to obtain this equilibrium.

The magnetic fields are capable of interaction with the plasma. One of these interactions is an inductively couplied of magnetic fields which vary in time with the plasma.

In ICP (Inductively Coupled Plasma) ionization is achieved by means of an induced current of high frequency.

ICP temperatures are very high $\left(4000-10000^{\circ} \mathrm{K}\right)$, sufficient to separate stable chemical combinations including refractory oxides, with chemical interferences being eliminated. This plasma may or may not be in thermodynamic equilibrium.

For ionization, the gas is made to circulate through a series of concentric tubes which make up the "TORCH", a key piece in plasma equipment. At the end of this "torch" there is an induction coil supplied by a high frequency generator.

In principle, it is necessary to initiate the ionization of the gas using an auxiliary medium, discharge of a Tesla coil, which is subsequently maintained by the high frequency current flowing through the induction coil. This has the effect of producing a magnetic field, with its lines of force axially oriented to the coil; this induces the ions and electrons to move in circular orbits, creating electric currents which cause the gases to heat, on account of the Joule effect, reaching temperatures of up to $10.000^{\circ} \mathrm{K}$, and provide for the continuity of the plasma.

Due to the ionized atoms, "flame" appears at the end of the torch, and this remains visible 
"llama" que se observa durante todo el proceso dé ensayo.

Como consecuencia de este diseño de la antorcha, las zonas axiales son relativamente frias, si se comparan con las circundantes y es, por tanto, a través de ellas por donde se inyectan las muestras dentro de la fuente de excitación y atomización, en forma de aerosol.

El sistema se basa en la observación de los espectros de emisión; los átomos excitados o ionizados emiten radiaciones (características para cada elemento) que, una vez focalizadas sobre un monocromador, se transforman eléctricamente en datos, de los que se obtendrán resultados cualitativos y cuantitativos.

\subsection{Descripción del Equipo}

El aparato adquirido por el Centro es el sistema ICP/5500 (Perkin-EImer) que comprende una fuente de Emisión por Plasma ICP y una unidad de Absorción Atómica, junto con el SISTEMA de PROCESO de DATOS modelo 10, y la IMPRESORA modelo PR-100, (figuras 1 y 2 ).

Las características generales de un equipo ICP y en particular las de éste son:

EL GAS PLASMOGENO utilizado es el más generalizado entre los sistemas de plasma: EL ARGON.

En el plasma existen las siguientes especies:

- Electrones libres.

- lones argón.



Fig. 1

Equipo ICP instalado en el Centro. ICP System. throughout the entire experimental process.

As a result of the way this torch is designed, the axial zones are relatively cold, in comparison with the surrouding areas, and, therefore, it is through these that the samples are injected into the excitation and atomization source, in aerosol-form.

The system is based on the observation of the emission spectra; the excited or ionized atoms emit radiations (characteristic for each element) which, are reflected into the monochromator, are electrically transformed into data from which the qualitative and quantitative results can be obtained.

\subsection{System Description}

The equipment acquired by the Centre is the ICP/5500 (Perkin-Elmer) system which includes an ICP Emission Source and an Atomic Absorption unit, together with the model 10 DATA STATION, and the model PR-100 PRINTER, (figures 1 and 2).

The general characteristics of ICP equipment and those referring specifically to this set are as follows:

THE GAS used as a plasma carrier is the most widespread among different systems: ARGON.

The following forms exist in the plasma:

- Free electrons.

- Argon ions.

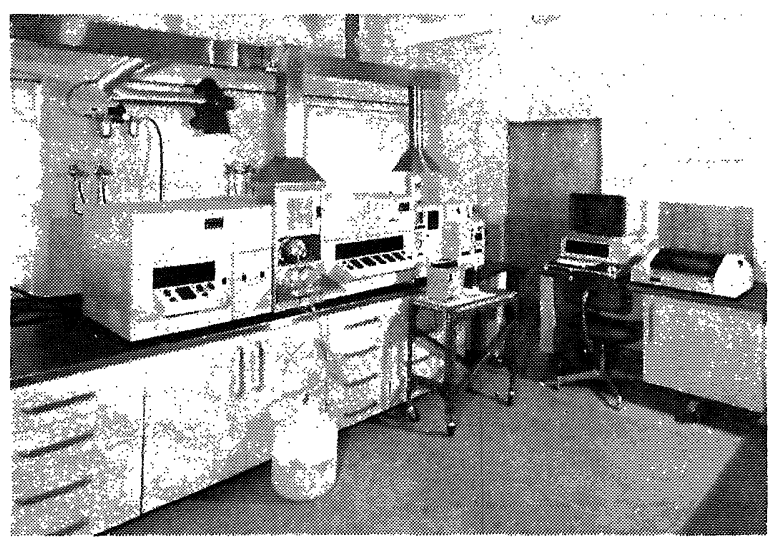

Fig. 2

Equipo ICP instalado en el Centro ICP System. 
- Atomos de argón excitados (dos especies "metaestables").

- Atomos de argón en estado fundamental.

- Moléculas de argón ionizadas y neutras.

Las tres primeras especies energéticas indicadas son capaces de ceder su energía a los átomos de los elementos de la muestra introducida en el plasma. Estas energías son suficientes para excitar a la mayoría de los átomos del sistema periódico.

La ANTORCHA está consituida por tres tubos de cuarzo dispuestos concéntricamente. Los más externos tienen la misión de transportar el gas plasmógeno (el argón); por el tubo interno (inyector) llega la muestra en forma de aerosol hasta el interior de la "llama" originada por el plasma.

Del diseño de la antorcha van a depender gran parte de las características del equipo, ya que condiciona no sólo el tiempo de permanencia de la muestra en la llama, que es la zona de excitación, sino que también el mantenimiento del equilibrio en el seno del plasma, está subordinado a su configuración. Esto hace que, para mejorar en la práctica la técnica ICP, las investigaciones estén encauzadas fundamentalmente hacia nuevos tipos de antorcha con el fin de optimizar el sistema.

La antorcha puede ser MONOBLOC, con tres tubos soldados formando una unidad o bien DESMONTABLE, con tubos independientes, lo que permite utilizar como inyector otro material (generalmente cerámico) para muestras ácidas.

Esta última modalidad es la utilizada en este caso. El tubo inyector es resistente a los ataques químicos de soluciones (al $50 \%$ ) de $\mathrm{HCl}, \mathrm{HNO}_{3}, \mathrm{H}_{2} \mathrm{SO}_{4}, \mathrm{H}_{3} \mathrm{PO}_{4}$, así como de $\mathrm{HF}$ y agua regia (al $20 \%$ ).

En la figura 3 se muestra una foto de la antorcha desmontada.

EI GENERADOR de radiofrecuencia aporta la energía externa al plasma, mediante un sistema de acoplamiento. La frecuencia utilizada varía según el tipo de control que posean (Tabla I).

\section{EI SISTEMA de INTRODUCCION de}

MUESTRAS que se utiliza en el equipo es el de uso más frecuente y consiste en la formación de aerosoles, generados a partir de soluciones de las mismas, con técnicas de nebulización. Para hacer llegar la muestra a la "Ilama" emplea una bomba peristáltica.
- Excited argon atoms (two "metastable" forms).

- Argon atoms in fundamental level.

- Ionized and neutral argon molecules.

The first three forms indicated transfer their energy to the atoms of the elements of the sample introduced into the plasma. These energies are sufficient to excite most of the atoms of the periodic system.

The TORCH is made up of three concentric quartz tubes. The outer tube carries the argon plasma support gas and the inner tube (injector tube) carries the sample nebulized into an Ar stream.

Many of the features of the equipment will depend on the design of the torch, since this is a conditioning factor not only for the time the sample remains in the flame, this being the excitation zone, but also for maintaining equilibrium within the plasma, and is subjected to its configuration. This means that for the ICP technique to be improved in practice, the researches should be mainly orientated towards new types of torch with the aim of optimizing the system.

The torch may be MONOBLOC, with three welded tubes forming a unit, or else DEMOUNTABLE, with independent tubes, enabling another material (normally ceramic) to be used as an injector for acid samples.

The latter modality is the one used in this case. The injector tube is resistant to the chemical attacks of (50\%) solutions of $\mathrm{HCl}, \mathrm{HNO}_{3}, \mathrm{H}_{2} \mathrm{SO}_{4}, \mathrm{H}_{3} \mathrm{PO}_{4}$, as well as those of HF.

Figure 3 shows a photo of the demounted torch.

The radio-frequency GENERATOR supplies the external power for the plasma by means coupling system. The frequency used varies according to the type of power control incorporated (Table I).

The used in the equipment is the one most the SAMPLE INJECTION SYSTEM commonly used consisting of the formation of aerosols, generated from solutions of these same samples, using nebulization techniques. A peristaltic pump is used to propel the sample towards the "flame". 




Fig. 3

Piezas de la Antorcha.

Parts of the torch.

TABLA I

Parámetros intrumentales

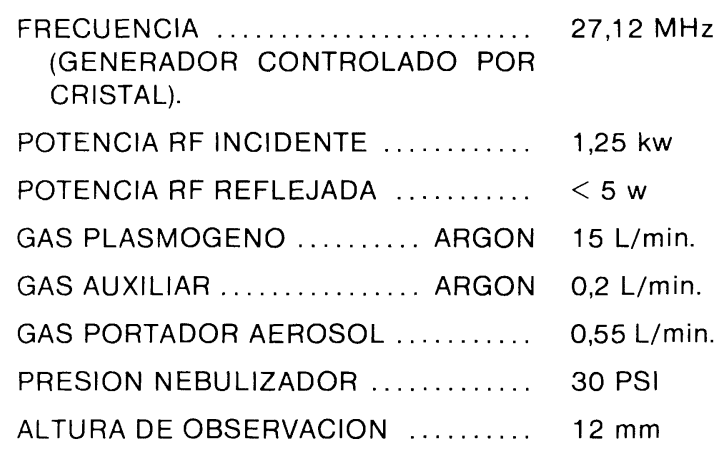

Esta etapa es importante a la hora de estudiar las posibles interferencias, ya que, en muchos casos, se deben a los efectos de nebulización y de transporte de la muestra (tiempo que tarda la muestra en llegar al plasma, ...) (28).

EI SISTEMA OPTICO, tiene como finalidad separar cada una de las radiaciones monocromáticas que forman el haz policromático y que permiten la identificación y cuantificación de cada uno de los elementos que constituyen la muestra, ya que la radiación electromagnética producida al liberar la energía absorbida en el plasma por los átomos así excitados para pasar a su estado fundamental es característica de cada elemento.

Los aparatos utilizados en espectroscopia de
Fig. 4

DOBLETES CARACTERISTICOS DEL BORO. Limites de detección de los dobletes del Boro a 208,89/208,96 y a $249,68 / 249,77 \mathrm{~nm}$.

BORON CHARACTERISTICS DOUBLETS. Detección limits Boron doublets at 208.89/208.96 and at 249,68/249.77 nm.

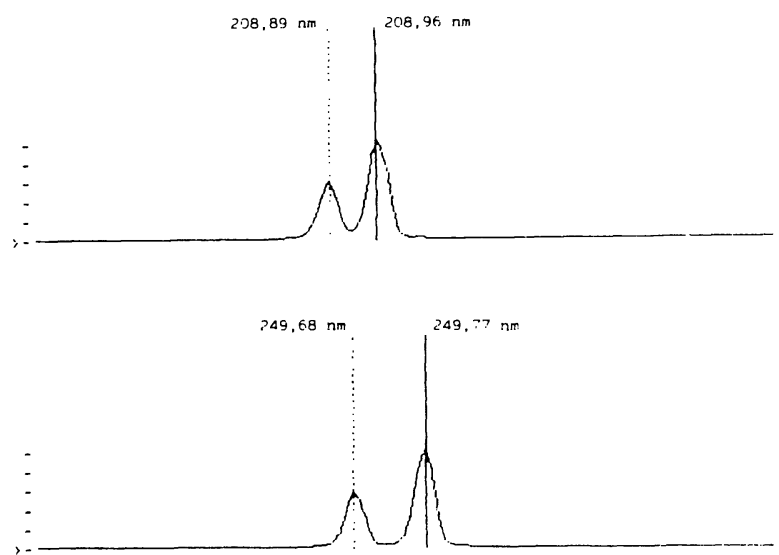

TABLE I

Instrumental parameters

\begin{tabular}{|c|c|}
\hline $\begin{array}{l}\text { FREQUENCY } \ldots \ldots \ldots \ldots \ldots \ldots \ldots \ldots \\
\text { (CRYSTAL-CONTROLLED GENERA- } \\
\text { TOR). }\end{array}$ & $27,12 \mathrm{MHz}$ \\
\hline INCIDENT RF POWER ............... & $1,25 \mathrm{kw}$ \\
\hline REFLECTED RF POWER $\ldots \ldots \ldots \ldots \ldots$ & $<5 w$ \\
\hline PLASMA GAS FLOW RATE ... ARGON & $15 \mathrm{~L} / \mathrm{min}$ \\
\hline AUXILIARY GAS FLOW RATE. ARGON & $0,2 \mathrm{~L} / \mathrm{min}$. \\
\hline AEROSOL CARRIER ARGON FLOW & $0,55 \mathrm{~L} / \mathrm{min}$. \\
\hline NEBULIZER PRESSURE & $30 \mathrm{PSI}$ \\
\hline VIEWING HEIGHT & $12 \mathrm{~mm}$ \\
\hline
\end{tabular}

This stage is important when it comes to studying possible interferences, since, in many cases, these are due to the effects of nebulization and the carriage of the sample (the time the sample takes to reach the plasma, ...) (28).

The OPTICAL SYSTEM has the purpose of separating each of the monochromatic radiations forming the polychromatic beam and enabling each of the elements making up the sample to be identified and quantified, since the electromagnetic radiation, produced by freeing the energy absorbed in the plasma by the atoms thus excited so that these assume their fundamental level, is characteristic of each element.

The apparatus used in emission spectroscopy 
emisión, se pueden dividir en dos tipos desde el punto de vista óptico (29):

- POLICROMATICOS, con una rendija de entrada y varias rendijas de salida (red de difracción fija): equipos multicanales.

- MONOCROMATICOS, con una rendija de entrada y una de salida (red de difracción móvil): equipos que proporcionan la determinación secuencial de elementos.

El equipo del Centro pertenece a esta última variedad. Posee dos redes, una holográfica con reflexión optimizada a $210 \mathrm{~nm}$ que se utiliza entre $175-465 \mathrm{~nm}$ y otra visible para longitudes de onda superiores a $460 \mathrm{~nm}$.

El camino óptico completo de ICP puede purgarse con argón o nitrógeno para eliminar el oxígeno, y permitir así determinaciones en el UV lejano (17).

Para análisis multielemento, el sistema determina los elementos SECUENCIALMENTE en orden ascendente de longitud de onda con cambio automático de red, si es necesario. Los instrumentos secuenciales tienen mejor poder de resolución, y no limitan el número de elementos a analizar.

El equipo permite la separación de haces monocromáticos muy próximos, lo que proporciona una buena resolución $(0,03 \mathrm{~nm})$, gracias a la cual se distinguen bandas de emisión muy próximas entre sí, como en el caso del boro, (fig. 4).

La radiación monocromática que sale a través de la rendija secundaria se recoge por un tubo fotomultiplicador, que transforma la señal óptica en impulsos eléctricos que se amplifican y se tratan para su identificación y cuantificación.

El equipo ICP/5500 incluye la técnica de ABSORCION ATOMICA y tiene la posibilidad de incorporar la cámara de grafito para casos especiales.

El sistema óptico es común para ambas técnicas. La utilización de ICP o AA dependerá del tipo de elemento a analizar; por ejemplo, los límites de detección en ICP para elementos refractarios son mucho mejores que los de AA; además, la línealidad analitica del ICP excede mucho a la de AA, (se extiende de centésimas o milésimas de ppm a cientos de ppm), por lo que se evitan problemas de dilución a la hora de analizar determinadas muestras. Sin embargo, la absorción atómica puede proporcionar un ensayo más preciso, debido a la especificidad espectral de la fuente de cátodo hueco. can be divided into two types from an optical point of view (29):

- POLYCHROMATIC, with one entrance slit and several exit slites (fixed diffraction grating): multichannel systems.

- MONOCHROMATIC, with one entrance slit and one exit slit (mobile diffraction grating): equipment providing for the sequential determination of elements.

The equipment of the Centre belongs to the latter variety. It has two gratings, a holographic one with optimized reflection at $210 \mathrm{~nm}$, used between 175-465 $\mathrm{nm}$ and another visible one for wavelengths of over $460 \mathrm{~nm}$.

The complete optical channel of the ICP can be purged with argon or nitrogen to eliminate the oxygen, thus allowing for determinations in the far UV (17).

For the analysis of multielements, the system determines the elements SEQUENTIALLY in ascending order of wavelength with an automatic change of network, where it is necessary. The sequential instruments have a greater resloving power, and do not limit the elements to be analyzed.

The equipment allows very close monochromatic beams to be separated, thus providing a good resolution $(0.03 \mathrm{~nm})$ thanks to which emission bands that are very close to one another can be distinguished, such as in the case of boron (fig. 4).

Monochromatic radiation emitted that passes through the exit slit to the photomultiplier tube detector which converts the optimal signal into electric pulses which are amplified and treated for idendification and quantification.

The $I C P / 5500$ system includes the ATOMIC ABSORPTION technique and has the possibility of incorporating a graphite furnace for special purpose.

The optical system is common for both techniques. The use of ICP or AA will depend on the type of element to be analyzed; for instance, the detection limits in ICP for refractory elements are much better than those of AA; furthermore, the analytic linearity of ICP greatly exceeds that of AA (it extends from hundredths or thousandths of ppm to hundreds of ppm), thus avoiding dilution problems when it comes to analyzing specific samples. AA, however, can provide more accurate testing, on account of the spectral specificity of the hollow cathode source. 
Por último, el equipo ICP del Centro, al igual que la mayoría de los existentes actualmente en el mercado, posee además un SISTEMA de PROCESO DE DATOS que ayuda al analista en todo el proceso, no sólo en el control del sistema óptico, introducción de la muestra y calibrado del equipo, sino también en la recogida y tratamiento de datos.

Es capaz de realizar la corrección de fondo o de solapamiento entre espectros y comprobar las posibles interferencias entre los elementos antes de proceder a un análisis cuantitativo.

EI SOFTWARE del sistema de proceso de datos permite operar de cuatro modos diferentes:

- El método operatorio "DESARROLLO" (DEVELOP) permite fijar todos los parámetros para la determinación de un elemento de la muestra a analizar, con la posibilidad de almacenarlos en un disco, y obtener así el análisis cualitativo de dicho elemento, así como sus posibles interferencias con otros elementos.

- El método operatorio "ANALISIS" (ANALYZE) hace posible la determinación cuantitativa secuencial, entre uno y ochenta elementos. Para ello se dispondrá del programa de análisis que se obtiene a partir de los programas aislados de cada uno de los elementos. Todos los datos pueden quedar almacenados en discos del propio ordenador.

Los elementos irán apareciendo en orden creciente de longitud de onda.

- El método operatorio "INFORME" (REPORT) permite la presentación de resultados en distintos formatos.

- Y por último, el método operatorio "BIBLIOTECA" (LIBRARY) mediante el cual se almacenan los datos para su utilización posterior.

\section{EJEMPLOS DE APLICACIONES ANALITICAS LLEVADAS A CABO CON EL EQUIPO ICP}

\subsection{Parámetros instrumentales}

Se recogen en la Tabla I.

\subsection{Análisis cualitativo de elementos minoritarios}

Aunque la misión principal de un equipo ICP
Finally, the ICP system of the Centre, like most of those currently available on the market, also has a DATA SYSTEM that helps the analyst throughout the entire process, not only in monitoring the optical system, introducing the sample and calibrating the system, but also in gathering and processing data.

It is capable of doing background correction or overlapping and checking possible spectral interferences between the elements before beginning the quantitative analysis.

The SOFTWARE pertaining to the data system allows for operation in four different ways:

- The "DEVELOP" mode allows all the parameters to be set for the determination of an element of the sample to be analyzed, with the possibility of stored on disk, thus obtaining the qualitative analysis of this element, as well as its possible interferences with other elements.

- The "ANALYZE" programation provides for the quantitative determination, in a manner, between one and eighty elements. In order to do this, the analysis program should be available. This is obtained from the programmes isolated from each of the elements. All the data may be stored on the computer's own disks.

The elements will appear in ascending order of wavelength.

- The "REPORT" mode enables results to be presented in different formats.

- Finally, the "LIBRARY" mode by means of which data us stored for subsequent use.

\section{EXAMPLE OF ANALYTIC APPLICATIONS CARRIED OUT WITH THE ICP SYSTEM}

\subsection{Instrumental parameters}

These are included in Table 1.

\subsection{Qualitative analysis of minoritary elements}

Despite the principal mission of ICP system 
sea la determinación cuantitativa de elementos, y si bien hay otras técnicas capaces de cualificar una muestra, existen ciertos casos en los que la verificación de la presencia de un elemento, incluso traza, es difícil de demostrar con los medios tradicionales disponibles, y sin embargo la técnica ICP permite detectarlo y, a continuación si se desea, cuantificarlo.

Este problema en concreto, se planteó en las investigaciones sobre la sintesis de un producto en el que se preveía la existencia de wolframio y de litio en su composición como elementos minoritarios. Para su identificación, se requirió la cooperación del Centro mediante el uso del equipo ICP.

\subsubsection{Resultados}

Las longitudes de onda elegidas para el análisis cualitativo de wolframio y de litio se recogen en la Tabla II.

\section{TABLA II}

Longitudes de onda características selecionadas para el análisis curativo

\begin{tabular}{|c|c|}
\hline ELEMENTO & $\begin{array}{c}\text { LONGITUD DE ONDA } \\
\text { (nm) }\end{array}$ \\
\hline \multirow{2}{*}{$W$} & 207,91 \\
& 209,48 \\
224,88 \\
\hline \multirow{2}{*}{$\mathrm{Li}$} & 232,26 \\
& 460,29 \\
\hline
\end{tabular}

La existencia de cada uno de los elementos analizados se verificó al obtener las bandas de emisión respectivas, que se ofrecen en la figura 5 para el wolframio y la figura 6 para el litio.

La cuantificación posterior de estos elementos ( $\mathrm{W}$ y $\mathrm{Li})$ no se llevó a cabo por no ser solicitada.

\subsection{Análisis cuantitativo en muestras entre cuyos elementos mayoritarios encuentra: $\mathrm{Si}, \mathrm{Al}, \mathrm{Fe}, \mathrm{Ca}$}

El modo de proceder con la técnica ICP se muestra en la descripción de un análisis cuantitativo de $\mathrm{Si}, \mathrm{Al}, \mathrm{Fe}$ y $\mathrm{Ca}$ en las tres muestras siguientes: un cemento portland, una puzolana natural, y una ceniza volante procedente de una central termoeléctrica. being the quantitative determination of elements, and even though other techniques exist capable of qualifying a sample, there are certain cases where the verification of the presence of an element, even a trace, proves difficut to demonstrate with the traditional means available; the ICP technique, however, enables this to be detected and, if wished subsequently quantified.

This problem in particular was raised in the research study conducted on the synthesis of a product in which the existence of wolfram and lithium was predicted in its composition as minoritary elements. To identify these elements, the cooperation fo the Centre was required for the use of the ICP system.

\subsubsection{Results}

The wavelengths selected for the qualitative analysis of wolfram and lithium are given in Table II.

TABLE II

Selectioned prominent lines of each element for its qualitative analysis

\begin{tabular}{|c|c|}
\hline ELEMENT & $\begin{array}{c}\text { WAVELENGTH } \\
\text { (nm) }\end{array}$ \\
\hline \multirow{2}{*}{$W$} & 207,91 \\
& 209,48 \\
224,88 \\
\hline $\mathrm{Li}$ & 232,26 \\
& 460,29 \\
\hline
\end{tabular}

The existence of each of the elements analysed was verified by obtaining the respective emission bands, which are shown in figure 5 for wolfram and figure 6 for lithium.

These elements ( $W$ and Li) were not quantified afterwards as this was not required.

\subsection{Quantitative analysis in samples featuring $\mathrm{Si}, \mathrm{Al}, \mathrm{Fe}, \mathrm{Ca}$ among their majority elements}

The method of procedure for the ICP technique is given in the description of a quantitative analysis of $\mathrm{Si}, \mathrm{Al}, \mathrm{Fe}$ and $\mathrm{Ca}$ in the following three samples: a portland cement, a natural pozzolan, and a fly ash from a thermo-electric power plant. 
Fig. 5

IDENTIFICACION DE WOLFRAMIO A PARTIR DE TRES DE SUS LONGITUDES DE ONDA CARACTERISTICAS:

$$
\begin{aligned}
& \text { A-207,91 nm } \\
& \text { B-209,48 nm } \\
& \text { C-224,88 nm }
\end{aligned}
$$

IDENTIFICATION OF TUNGSTEN FROM THREE OF ITS PROMINENT LINES:


\subsubsection{Preparación de las muestras}

La puesta en solución de cada una de las muestras se llevó a cabo de la siguiente manera:

En un reactor se introducen: $0,5000 \mathrm{~g}$ de muestra (de una superficie especifica entre $3.500-4.000 \mathrm{~cm}^{2} / \mathrm{g} \mathrm{u}$. Blaine), $3 \mathrm{~mL}$ de $\mathrm{HCl}$ conc. (d:1,18 g/cc), $3 \mathrm{~mL}$ de HF conc. $(48 \%)$ y unas gotas de $\mathrm{HNO}_{3}$ conc. (d:1,38 g/cc), se añade agua bidestilada, se introduce una pieza de agitación magnética recubierta de PTFE y se cierra el reactor. A continuación se calienta a $130^{\circ} \mathrm{C}$ y se mantiene en agitación contínua durante 30-45 minutos, al cabo de los cuales se deja enfriar hasta alcanzar la temperatura ambiente (o bien bruscamente en chorro de agua fría).

Se abre el reactor y se añaden $60 \mathrm{~mL}$ de $\mathrm{H}_{3} \mathrm{BO}_{3}$ (pureza 99,8 \% min.) al $5 \%$. Se agita de nuevo unos minutos. Se filtra y se lleva a un volumen fijo, en matraz aforado, de $1.000 \mathrm{~mL}$.

De este modo la muestra queda toda en solución y no hay residuo sólido.
Fig. 6

IDENTIFICACION DE LITIO A PARTIR DE DOS DE SUS LONGITUDES DE ONDA CARACTERISTICAS:

$$
\begin{aligned}
& \text { A-323,26 nm } \\
& \text { B-460,29 nm }
\end{aligned}
$$

IDENTIFICATION OF LITHIUM FROM TWO OF ITS PROMINENT LINES

A-323,26 $\mathrm{nm}$

$B-460,29 \mathrm{~nm}$
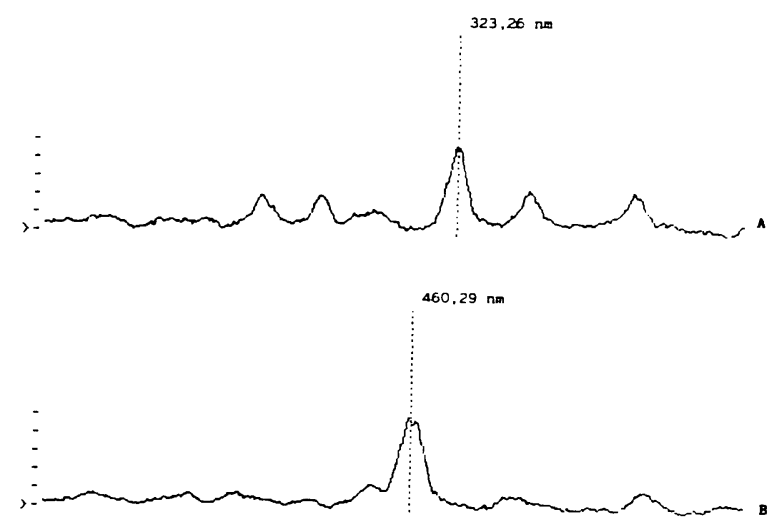

3.3.1. Sample preparation

Each of the samples was taken into solution in the following way:

$0,5000 \mathrm{~g}$ of sample (with a specific surface area of between $3500-4000 \mathrm{~cm}^{2} / \mathrm{g} \mathrm{u}$. Blaine), $3 \mathrm{~mL}$ of $\mathrm{HCl}$ conc. (d: $1.18 \mathrm{~g} / \mathrm{cc}$ ), $3 \mathrm{~mL}$ of $\mathrm{HF}$ conc. (48 \%) and a few drops of $\mathrm{HNO}_{3}$ conc. (d: $1.38 \mathrm{~g} / \mathrm{cc}$ ) are introduced into a reactor with bidistillated water; then a magnetic agitation element covered with PTFE is introduced and the reactor closed. This is then heated to $130^{\circ} \mathrm{C}$ and maintained in continuous agitation for 30-45 minutes, after which it is left to cool until it reaches rroom temperature (or else cooled quickly under a jet of cold water).

The reactor is opened and $60 \mathrm{~mL}$ of $\mathrm{H}_{3} \mathrm{BO}_{3}$ (99.8\% minimum purity) at $5 \%$ is added. It is then agitated again for a few minutes and subsequently filtered and conveyed to a $1.000 \mathrm{~mL}$ set volume in a volumetric flask.

In this way, the sample remains entirely in solution and there is no solid residue. 
3.3.2. Estudio de interferencia y selección de bandas en la aplicación de la técnica ICP a las muestras en estudio

Todas las técnicas de emisión están sujetas al hecho de que, uno o más elementos de la matriz de muestra tienen líneas de emisión que coinciden con la línea deseada del analítico. Por ello resulta imprescindible, antes de realizar un análisis de tipo cuantitativo, comenzar por un estudio exhaustivo de las posibles interferencias en los elementos a analizar, tanto por las ocasionadas por los elementos que posee la propia muestra, como por aquellos que están presentes en la disolución, y así elegir las longitudes de onda aptas.

En este caso concreto, se seleccionarán las longitudes de onda idóneas para la cuantificación de silicio, aluminio, hierro y calcio en cada una de las muestras, y que no presenten interferencias espectrales.

El estudio se simplifica gracias al Sistema de Proceso de Datos.

En la figura 7 se representa, como ejemplo, el estudio de interferencias espectrales para el elemento $\mathrm{Ca}$, en su banda de emisión a $396,86 \mathrm{~nm}$, tal como se lleva a cabo con el Sistema de Proceso de Datos y con el uso exclusivo de su pantalla y que, en este caso, se ha registrado con la impresora para su explicación.

El modo de proceder es el siguiente:

Se selecciona una banda de emisión del elemento a estudiar, o sea del $\mathrm{Ca}$, entre las de mayor intensidad (ej.: 395,85 $\mathrm{nm}$ ) y se observa si presenta solapamiento espectral con cada uno de los otros elementos que se deseen cuantificar simultáneamente. En este caso con el $\mathrm{Al}, \mathrm{Si}$ y $\mathrm{Fe}$. De esta forma se recogen sobre el espectro del Ca que aparece en pantalla con su banda de emisión a 396,85 nm (fig. $7 \mathrm{~A}$ ), el espectro en iguales condiciones de los demás elementos en orden sucesivo, primero del Al (fig. $7 \mathrm{~B}$ ), y aparece una línea recta en la base, lo que indica ausencia de banda de emisión, se borra de la pantalla la emisión del $\mathrm{Al}$ y se prosigue con el $\mathrm{Si}$ (fig. $7 \mathrm{C}$ ) y después con el Fe (fig. $7 \mathrm{D}$ ), obteniéndose también en ambos casos su correspondiente línea recta.

Por lo tanto el Ca se puede cuantificar en presencia de $\mathrm{Al}$, Si y $\mathrm{Fe}$, mediante la banda de emisión a 396,85 $\mathrm{nm}$, ya que no existen interferencias con los restantes elementos.

De modo análogo se ha procedido con cada
3.3.2. Research on interferences and band selection in applying the ICP technique to the samples under study

All emission techniques are subjectect to the fact that one element or more of the main sample has emission lines coinciding with the desired of the analyte. For this reason, before conducting analysis of a quantitative nature, it is essential to start with an exhaustive study of the possible interferences in the elements to be analysed, both due to those caused by elements contained in the sample itself, and also those present in the solution, thus selecting the appropriate wavelengths.

In this specific case, the wavelengths that are most suitable for quantifying silicon, aluminium, iron and calcium in each on the samples and that do not present any spectral interferences should be selected.

The study is simplified thanks to the Data System.

As an example, the study on spectral interferences is presented in figure 7 for the Ca element in its emission band at $396.86 \mathrm{~nm}$, just as it is conducted with the Data System and the exclusive use of its display unit; in this case, the study is explained by recording it with the printer.

The procedure is as follows:

An emission band is selected from the element under study, that is to say, from $\mathrm{Ca}$, from those of greatest intensity (eg.; $395.85 \mathrm{~nm}$ ) and it is observed to see whether there is any spectal overlapping wit each of the other elements it is wished to quantify at the same time in this case, with Al, Si, and Fe. These spectra pertaining to the other elements are thus collected on the Ca spectrum appearing on the display unit with its emission band at $396.85 \mathrm{~nm}$ (fig. 7A) in identical conditions, and in consecutive order, starting with that of Al (fig. 7B), and a straight line appears at the bottom, indicating an absence of emission band; the Al emission is then erased from the screen and the process is continued with $\mathrm{Si}$ (fig. 7C) and then wih Fe (fig. 7D), obtaining the corresponding straight line in both cases.

Ca can therefore be quantified in the presence of $\mathrm{Al}$, Si and $\mathrm{Fe}$, with the emission band at $396.85 \mathrm{~nm}$, as there is no interference with the other elements.

A similar method has been used for each of 
uno de los otros elementos a analizar, para verificar la ausencia de interferencias, y se ha llegado así a la selección de longitudes de onda que se exponen en la Tabla III.

TABLA III

Longitudes de onda características seleccionadas para el análisis cuantitativo

\begin{tabular}{|c|c|}
\hline ELEMENTO & $\begin{array}{c}\text { LONGITUD DE ONDA } \\
\text { (nm) }\end{array}$ \\
\hline $\mathrm{Si}$ & 251,61 \\
$\mathrm{Al}$ & 308,22 \\
$\mathrm{Fe}$ & 259,94 \\
$\mathrm{Ca}$ & 396,85 \\
\hline
\end{tabular}

the other elements to be analysed to verify the absence of interference, and thus select the appropriate wavelengths shown in Table III.

TABLE III

Selectioned prominent lines of each element for its quantitative analysis

\begin{tabular}{|c|c|}
\hline ELEMENT & $\begin{array}{c}\text { WAVELENGTH } \\
\text { (nm) }\end{array}$ \\
\hline $\mathrm{Si}$ & 251,61 \\
$\mathrm{Al}$ & 308,22 \\
$\mathrm{Fe}$ & 259,94 \\
$\mathrm{Ca}$ & 396,85 \\
\hline
\end{tabular}

Fig. 7

ESTUDIO DE INTERFERENCIA PARA EL CALCIO EN SU BANDA DE EMISION A 396,85 nm, EN PRESENCIA DE $\mathrm{Al}$, Si y $\mathrm{Fe}$.

STUDY OF THE INTERFERENCES OF Al, Si and Fe ELEMENTS ON THE DETERMINATION OF CALCIUM (LINE: $396.85 \mathrm{~nm}$ ).

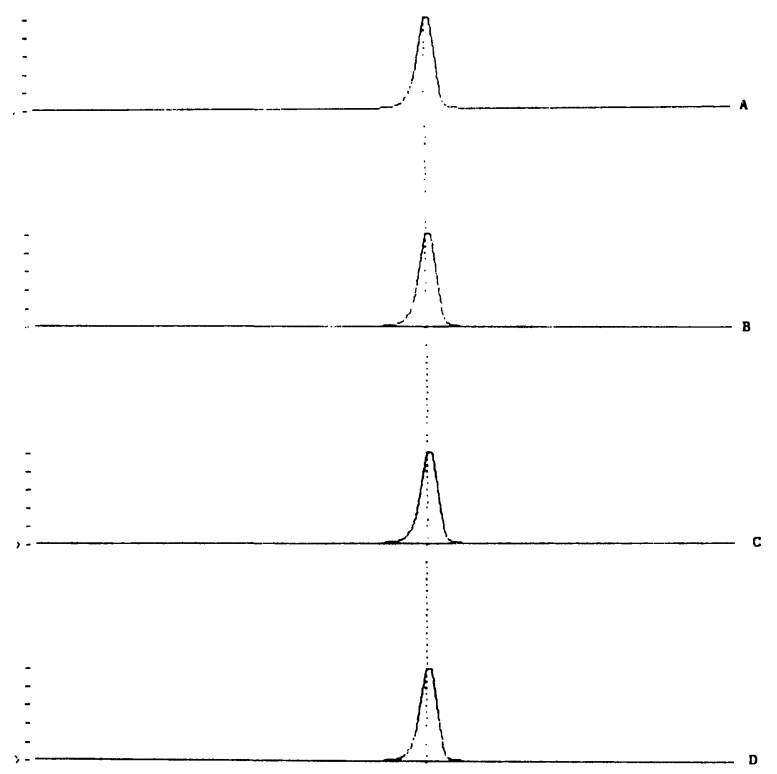

\subsubsection{Resultados}

Una vez seleccionadas las longitudes de onda para cada elemento (Tabla III), se hace el calibrado de cada una de ellas, y se introduce esta información junto con las condiciones de análisis y concentración de los patrones utilizados en un disco a disposición del Sistema de Proceso de Datos.

\subsubsection{Results}

Once the wavelengths have been selected for each element (Table III), they are all calibrated, and this information is introduced in a disk available to the Data System, together with the conditions for analysis and concentration of the standards used. 
En la figura 8 se presenta dicha información tal como aparece en pantalla para cada elemento a analizar ( $\mathrm{Si}, \mathrm{Al}, \mathrm{Fe}$ y $\mathrm{Ca}$ ).

El análisis cuantitativo se realiza mediante el método operativo "ANALISIS".

La composición de las muestras analizadas, un cemento portland, una puzolana natural y una ceniza volante, expresada en \% en óxidos, calculados a partir de los valores obtenidos por el ICP para cada uno de los elementos en ppm, se encuentra en la tabla IV.

TABLA IV

Composición de las muestras analizadas

(\% en óxidos) calculadas a partir de los valores obtenidos por ICP de los elementos (en $p p m$ )

\begin{tabular}{|l|r|r|r|c|}
\hline \multirow{2}{*}{ MUESTRA } & \multicolumn{4}{|c|}{ COMPOSICION (\%) } \\
\cline { 2 - 5 } & $\mathbf{S i O}_{2}$ & $\mathrm{Al}_{\mathbf{2}} \mathrm{O}_{\mathbf{3}}$ & $\mathrm{Fe}_{\mathbf{2}} \mathrm{O}_{\mathbf{3}}$ & $\mathrm{CaO}$ \\
\hline $\begin{array}{l}\text { CEMENTO } \\
\text { PORTLAND }\end{array}$ & 19,20 & 5,95 & 1,81 & 62,24 \\
\hline $\begin{array}{l}\text { PUZOLANA } \\
\text { NATURAL }\end{array}$ & 44,60 & 17,87 & 12,90 & 10,63 \\
\hline $\begin{array}{l}\text { CENIZA } \\
\text { VOLANTE }\end{array}$ & 45,30 & 36,70 & 7,40 & 4,50 \\
\hline
\end{tabular}

This information is presented in figure 8 just as it appears on the display unit for each element being analysed ( $\mathrm{Si}, \mathrm{Al}, \mathrm{Fe}$ and $\mathrm{Ca}$ ).

Quantitative analysis is conducted by means of the "ANALYZE" program.

The composition of the samples analysed, a portland cement, a natural pozzolan, and a fly ash, expressed in \% in oxides, and calculated from values obtained for ICP for each of the elements in ppm, are given in Table IV.

TABLE IV

Composition of the analysed samples

(\% oxides) calculated from obtained values of the element by ICP (in ppm)

\begin{tabular}{|l|r|r|r|r|}
\hline \multirow{2}{*}{ SAMPLE } & \multicolumn{4}{|c|}{ COMPOSITION (\%) } \\
\cline { 2 - 5 } & $\mathrm{SiO}_{2}$ & $\mathrm{Al}_{2} \mathrm{O}_{3}$ & $\mathrm{Fe}_{2} \mathrm{O}_{3}$ & $\mathrm{CaO}$ \\
\hline $\begin{array}{l}\text { PORTLAND } \\
\text { CEMENT }\end{array}$ & 19,20 & 5,95 & 1,81 & 62,24 \\
\hline $\begin{array}{l}\text { NATURAL } \\
\text { POZZOLAN }\end{array}$ & 44,60 & 17,87 & 12,90 & 10,63 \\
\hline FLY ASH & 45,30 & 36,70 & 7,40 & 4,50 \\
\hline
\end{tabular}

Fig. $8 \mathrm{~A}, \mathrm{~B}, \mathrm{C}$ y $\mathrm{D}$

CONDICIONES DE ANALISIS INTRODUCIDAS EN EL SISTEMA DE PROCESO DE DATOS PARA CADA ELEMENTO: $\mathrm{A}-\mathrm{Si}$; B-Al; C-Fe; D-Ca

ANALYTICAL CONDITIONS ENTERING IN THE DATA SYSTEM FOR EACH ELEMENT:

A-Si; B-Al; C-Fe; D-Ca

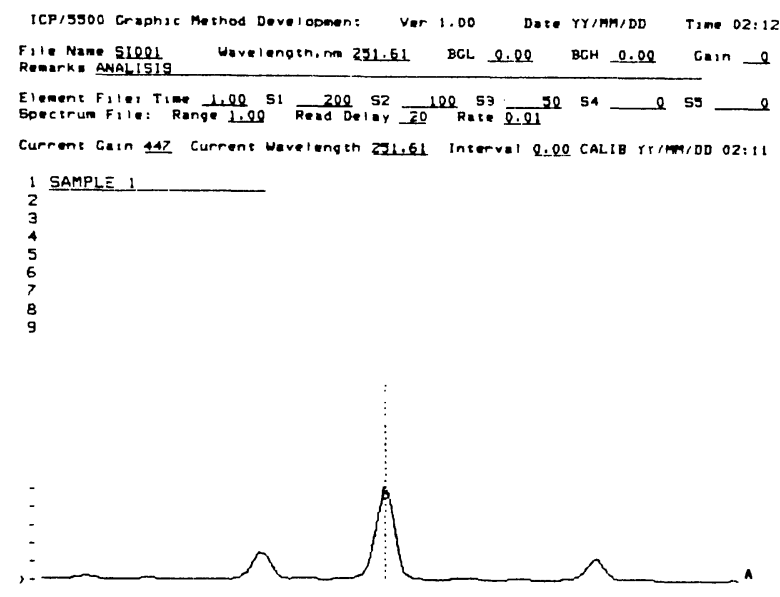

Fig. $8 \mathrm{~A}$

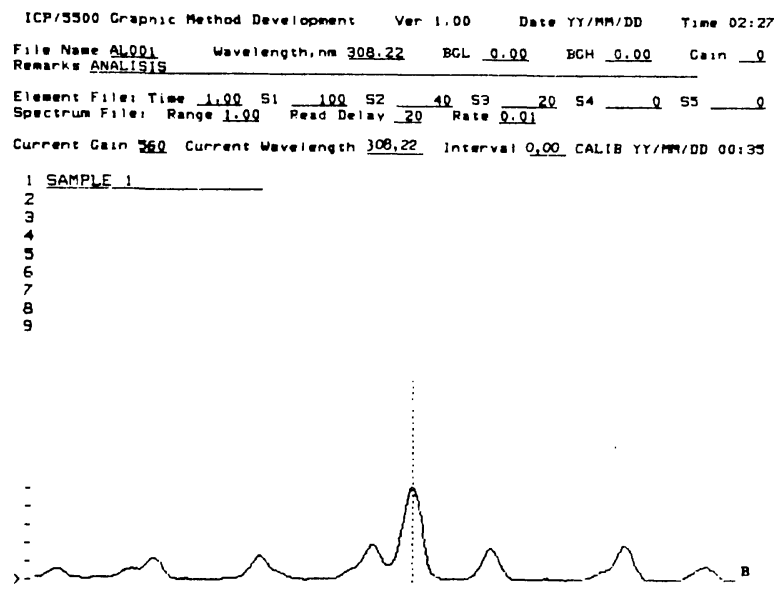

Fig. 8 B 


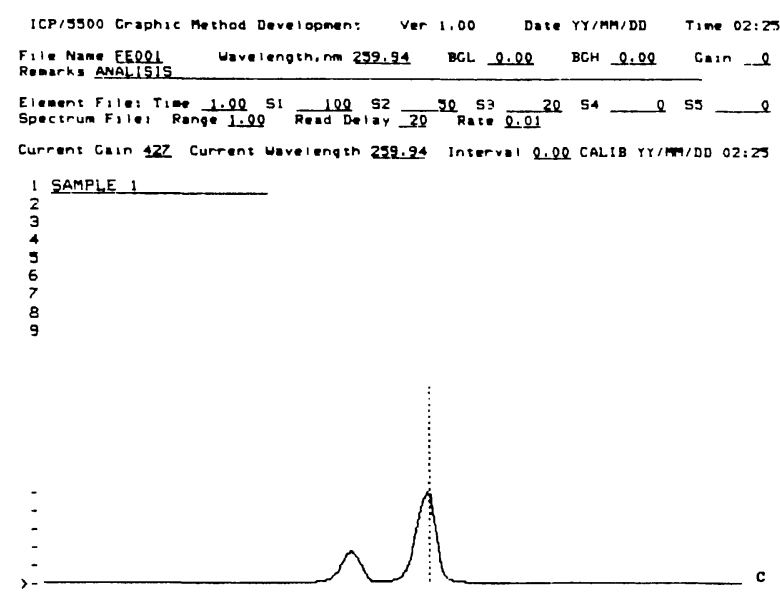

Fig. $8 \mathrm{C}$

\section{CONSIDERACIONES FINALES}

- La técnica ICP es todavía muy nueva y, por esto, más susceptible que otras a la posibilidad de mejorar. Las líneas que están actualmente en estudio con este fin, contemplan prioritariamente:

- El gas plasmógeno, con la sustitución del argón por otros gases, como el helio, que proporcionen mayor energía al plasma.

- La antorcha, con la búsqueda de nuevos diseños.

- El sistema de introducción de las muestras, para evitar al máximo las posibles interferencias.

- A lo largo de este artículo, se han destacado muchas de las ventajas de la técnica de emisión por fuente de plasma acoplado inductivamente frente a otras técnicas hoy en uso, y se han citado estudios que ofrecen comparaciones entre los diferentes métodos analíticos, (7) (9) (23) (24) (25) (27). La práctica será la que, dentro de unos años, tras el desarrollo tecnológico, las delimitará plenamente.

- La espectrometría de emisión con plasma acoplado inductivamente (ICP) es válida para el análisis de los elementos de materiales en el campo de la construcción: cemento, clínker, cenizas volantes, puzolanas, ... como se pone de manifiesto tanto por la recopilación bibliográfica de los aún escasos estudios realizados, como por los resultados experimentales presentados obtenidos por el equipo de Centro, que son el principio del desarrollo de esta técnica analítica en investigaciones futuras.

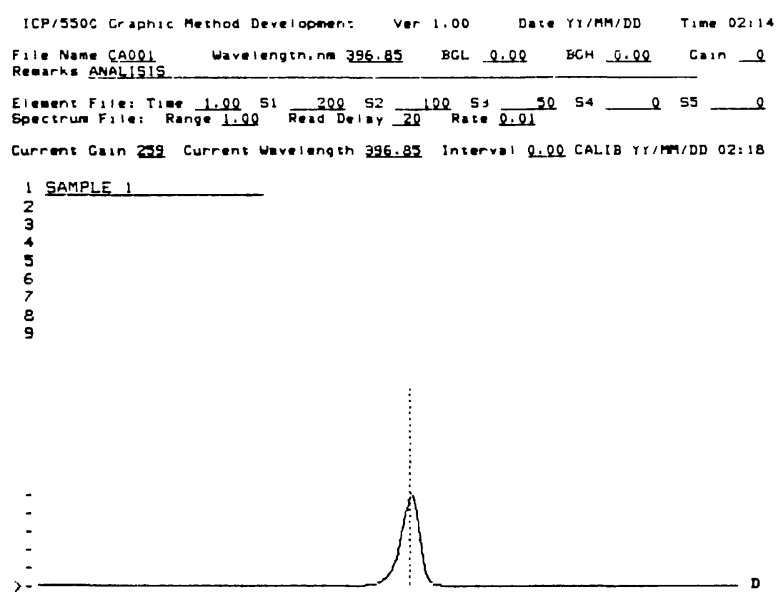

Fig. $8 \mathrm{D}$

\section{FINAL REMARKS}

- The ICP system is still very new and, consequently, more susceptible than others to the possibility of improvement. The lines currently under study with this aim in mind are mainly concerned with:

- The gas used a plasma carrier, with argon being substituted by other gases, such as helium, that provide greater power for the plasma.

- The torch, with the search for new designs.

- The sample injection so as to avoid possible interferences to the utmost.

- Throughout this paper attention has been drawn to many of the advantages of the inductively coupled plasma emission technique, compared to other techniques currently in use and studies have been mentioned that provide comparisons between various analytic methods, (7), (9), (23), (24), (25), (27). It will be practical experience that fully delimits these methods in a few years' time, following technological development.

- Inductively coupled plasma emission spectrometry (ICP) is valid for analysing the elements of materials in the field of construction work: cement, clinker, fly ash, pozzolans,... as indicated by the bibliographical compilation of the few studies that have been carried out so far, as well as the experimental results that have been obtained and presented by the Centre's equipment, signifying the start of the development of this analytic technique in future research work. 
- La aplicación de la técnica ICP, por sus características específicas, tiene interés especial en líneas de investigación de actualidad, como por ejemplo:

- Fabricación de clínker: Influencia de la naturaleza de las materias primas, sobre la estructura y propiedades del clínker (29), (30).

- Caracterización de productos.

- Hidratación de la pasta de cemento portland:

Efecto producido por la presencia de: $\mathrm{B}$ (31), Zn (32) (33), S (34) (35), Mn (36), Mg (37) (38), Ca (39) Pb (39), ...

- Influencia en la salud humana (dermatogía, ....) de la presencia de determinados elementos en bajo porcentaje (40) [Talio (40) (41) (42), ...].

- Etc. ...
- The application of the ICP technique has special interest, due to its specific features, in current lines fo research, such as, for example:

- Manufacturation of clinker:

Influence of the nature of raw materials on the structure and properties of clinker (29) (30).

- Characterization of products.

- Hydration of portland cement paste:

Effect produced by the presence of: $B$ (31), Zn (32) (33), S (34) (35), Mn (36), $\mathrm{Mg}$ (37) (38), Ca (39) $\mathrm{Pb}$ (39), ...

- Influence on human health (dermatology, ...) of the presence of specific elements in small percentages (40) [Thallium (40) (41) (42), ...].

- Etc. ...

\section{B I B L IOG RAF I A}

(1) REED, T.B., J. Appl. Phys., 32, 821, 2.534, (1961)

(2) REED, T. B.: Int. Soc. Technol., 42, (1962).

(3) GREENFIELD, S., JONES I. L., BERRY C. T.: Analyst, 89, 713, (1964).

(4) GREENFIELD, S.: Proc. Soc. Anal. Chem., 2, 111, (1965).

(5) WENDT R. H., FASSEL V. A.: Anal. Chem., 37, 920, (1965).

(6) FASSEL V. A., DICKINSON G. W.: Anal. Chem., 40, 247 (1968).

(7) FASSEL V. A., KNISELEY R. N.: Anal. Chem., 46, n. 13, 1110 A y 1155 A, (1974).

(8) SCOTT R. H., FASSEL V. A., KNISELEY R. N., NIXON D. E.: Anal. Chem., 46, n. 1, 75-80, (1974).

(9) KAWAGUCHI K.: Bunseki, 34, 612-618, (1975).

(10) ALLAIN P., MAURAS Y.: Anal. Chem., 51, 2089-2091, (1979).

(11) WINGE R. K., PETERSON V. J., FASSEL V. A.: Appl. Spectros., 33, n. 3, 206-219, (1979).

(12) SCHMIDT G. J., SLAVIN W.: Anal. Chem., 54, 2491-2495, (1982).

(13) HILLIGOSS D. R., PARMAN M. R.: ICP Bull., n. 1, (1983).

(14) PRUSZKOWSKA E., BARRETT P., EDIGER R., WALLACE G.: At. Espectrosc., 4 n. 3, 94-98, (1983).

(15) FEENEY C. M., ANDERSON J. W., TINDALL F. M.: At. Espectrosc., 4, n. 3, 108-110, (1983).

(16) MAURAS Y., ALLAIN P.: Anal. Chem., 57, n. 8, 1706-1709, (1985).

(17) VEHIRO T., MORITA, M., FUWA K.: Anal. Chem., 57, n. 8, 1709-1713, (1985).

(18) TAKEMOTO K., UCHIKAWA H.: $7^{\text {th }}$ Int. Symp. Chem. Cement, I, París, 1, (1980).

(19) BURMAN J. O., PONTER C., BOSTRON K.: Anal. Chem., 50, 679, (1978).

(20) SCOTT R. H., KOKOT M. L.: Anal. Chim. Acta, 75, 257, (1975).

(21) DEBRAS-GUEDON J., BISSON G.: Bull. S.F.C., n. 108, (1975).

(22) DEBRAS-GUEDON J.: Bull. S.F.C. (L'Ind. ceram.), n. 761, 379-386, (1982).

(23) DEGRE J. P., RIVAL A.: Silicates Ind. 47, n. 1, 17-22, (1982). 
(24) DEGRE, J. P.: Rev. Mater. Cim. Bét. Plât. Chaux, n. 735, 76-80, (1982).

(25) NADKARNI R. A.., BOTTO R. I., SMITH S. E.: At. Spectrosc., 3, n. 6, 180-184, (1982).

(26) MARABINI A. M., BARBARO M., PASSARIELLO B.: At. Spectrosc. 6, n. 3, 74-75, (1985).

(27) GOMEZ COEDO A.: Quim. Ind., 28, ns. 7 y 8, 525-531, (1982).

(28) VINDEL A.: Quim. Ind., 31, n. 3, 177-182, (1985).

(29) BUCCHI R.: $7^{\text {th }}$ Int. Symp. Chem. Cement., I, n.1, 3-44, Paris (1980).

(30) PEZZUOLI M.: $6^{\text {th }}$ Int. Symp. Chem. Cement. I. Moscow (1974).

(31) LIEBER von W.: Zement Kalk Gips, 34, n. 9, 473-475, (1981).

(32) ARLIGUeG., DUVAL R., LONGUeT P.: Cim. Bét. Plât. Chaux, n. 719, 201-206, (1979).

(33) ARLIGUE G., OlLIVIER J. P., GRANDET J.: Cem. Concr. Res. 12, n. 1, 79-86, (1982).

(34) VERNET CH.: Silicates Ind., 47, n. 3, 85-90, (1982).

(35) RECHENBERG W.: Zement Kalk Gips, 33, n. 3, 126-131, (1980).

(36) KNÖFEL D., STRUNGE J., BAMBAUER H. U.: Zement Kalk Gips., 36, n. 7, 402-408, (1983).

(37) DREOIZLER on I., KNÖFEL D.: Zement Kalk Gips, 35, n. 10, 537-550, (1982).

(38) RAMACHANDRAN V. S.: II Cemento, n. 3, 159-168, (1980).

(39) ALFORD N. Mc. N., RAHMAN A. A., SALIH N.: Cem. Concr. Res., 11, n. 2, 235-245, (1981).

(40) SCHULZE K. H.: Zement Kalk Gips, 36, n. 1, 7-11, (1983).

(41) RECHENBERG on W.: Zement Kalk Gips, 35, n. 2, 90-95 (1982).

(42) DEANE P. G.: Zement Kalk Gips, 35, n. 10, 526-529, (1982).

\section{publicación del i.e.t.c.c.}

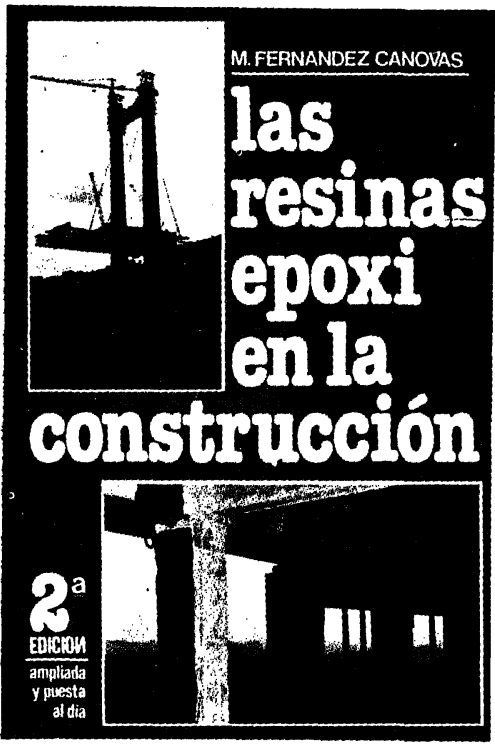

Manuel Fernández Cánovas

Dr. Ingeniero de Construcción

Este libro, el primero en lengua castellana sobre resinas epoxi aplicadas a la construcción, está dirigido a arquitectos, ingenieros, constructores y aplicadores. En él, sobre una reducida base teórica imprescindible, se asienta toda una extensa gama de aplicaciones de gran interés.

El autor trabaja desde hace muchos años en el campo de la investigación, especialmente en el estudio de refuerzos y reparaciones estructurales realizados con resinas epoxi.

Con un lenguaje sencillo se tocan todos los problemas que pueden presentarse en la construcción y en los que la solucićn puede radicar en el correcto empleo de las resinas epoxi.

Se estudian los componentes de las formulaciones epoxi. sus propiedades fisicas y quimicas, y aplicaciones, deteniéndose, detalladamente, en las siguientes:

Unión de hormigón fresco a hormigón endurecido. - Unión de hormigones entre si. - Inyecciones de fisuras y grietas. - Unión de acero a hormigón. - Barnices y pinturas. - Las combinaciones brea-epoxi. - Revestimientos de depósitos alimenticios. - Sellado de superficies cerámicas. - Protección de tubos. - Los suelos epoxi en sus diferentes variantes. - Terrazo epoxi. - Reparación de baches. - Reparación de desperfectos en estructuras. - Reparación de carreteras de hormigonn. - Juntas elásticas. - Guardacantos de tableros de puenes. - Refuerzos de pil vigas, forjados y zapatas, etc. - Consolidación de suelos.-Anclajes. - Protección de aceros en pretensado.

Se termina con unos capitulos dedicados a la limpieza y preparación de las superficies según los materiales a unir; al control del estado superficial de éstos; a las condiciones de temperatura de aplicación; limpieza de los útiles de trabajo; precauciones en el manejo de los sistemas; almacenaje, mezcla y manejo de las formulaciones epoxi y métodos de ensayo de sistemas y aplicaciones epoxidicas.

Un volumen encuadernado en cartoné plastificado con lomo de tela, de $17 \times 24 \mathrm{~cm}$, compuesto de 334 páginas y 158 figuras y fotografias.

Madrid, 1981.

Precios: España, 1.700 ptas.; extranjero, \$ USA 34.00 